\title{
The treatment of childhood cancer: unveiling the experience of parents ${ }^{1}$
}

\author{
Gabriella Michel dos Santos Benedetti \\ Mara Lúcia Garanhani ${ }^{3}$ \\ Catarina Aparecida Sales ${ }^{4}$
}

Objective: to understand the experiences of parents of children and adolescents with cancer undergoing treatment. Method: qualitative research, based on Heidegger's existential phenomenology, in which 13 parents of eight patients under 19 years of age, assisted by a charity association, were interviewed. Results: three topics resulted from the analysis: "Experiencing the unpleasantness of the treatment"; "Fearing the possibility of a frightening situation" and "Experiencing the carelessness of another person". It was showed that during and after the treatment, the parents experience the fear of the unknown and the uncertainty of the future of their children, especially as they witness the death of other children; they also experience the indifference of professionals working in the local healthcare units and feel helpless and insecure. Conclusion: It is essential that the healthcare professionals, particularly the nurses, reflect about their care actions focused on the parents of children with cancer, recognizing their existential needs with the purpose of assisting them in their situation.

Descriptors: Parents; Child; Adolescent; Neoplasms; Nursing.

\footnotetext{
${ }^{1}$ Paper extracted from master's thesis "Parents' experiences of children and adolescents suffering from cancer: an existential phenomenological approach", presented to Universidade Estadual de Maringá, Maringá, PR, Brazil.

2 MSc, Collaborating Professor, Departamento de Enfermagem, Universidade Estadual do Paraná, Paranavaí, PR, Brazil.

${ }^{3} \mathrm{PhD}$, Associate Professor, Departamento de Enfermagem, Universidade Estadual de Londrina, Londrina, PR, Brazil.

${ }^{4} \mathrm{PhD}$, Adjunct Professor, Universidade Estadual de Maringá, Maringá, PR, Brazil.
}

Corresponding Author:

Gabriella Michel dos Santos Benedetti

Rua Dário Veloso, 88

Centro

CEP: 87840-000, Mirador, PR, Brasil

E-mail: enfermeiragabi@hotmail.com
Copyright () 2014 Revista Latino-Americana de Enfermagem This is an Open Access article distributed under the terms of the Creative Commons Attribution Non-Commercial License (CC BY-NC).

This license lets others distribute, remix, tweak, and build upon your work non-commercially, and although their new works must also acknowledge you and be non-commercial, they don't have to license their derivative works on the same terms. 


\section{Introduction}

The treatment of childhood cancer has made significant progress in the last decades due to the techniques of early diagnosis and the development of therapeutic methods ${ }^{(1)}$. Each of these methods present particularities, recommendations, limits, benefits, as well as possible complications ${ }^{(2)}$.

In various situations, the antineoplastic therapy has stigmas designated by the general population, as those attributed to cancer, since it can cause severe side effects $^{(3)}$, causing as much fear, pain and suffering as the disease itself. Despite this, it can also represent a source of hope in the cure or longer life expectancy ${ }^{(3-4)}$.

It is in this search for the cure that the children is faced with inevitable changes to their lives, being forced to stay in bed, and experiencing the regular contact with unfamiliar people, the practice of uncomfortable procedures, changes in their diet, separation from family, friends, school, among other experiences(3). Adolescents, in turn, realize the changes in their image, which changes their personality and puts them in a new and scary world(5).

Every day of treatment also represents a new challenge for the family, which get together and make themselves available to help the sick person, staying with them and witnessing the limitations imposed by the disease, besides feeling distressed while witnessing their pain and their reduced quality of life ${ }^{(6)}$.

From this perspective, it is not easy to face childhood cancer, especially due to its instability caused by stressful events that greatly affect parents ${ }^{(7)}$, since they are continuously confronted with the uncertainty about the cure and the likelihood their children could $\mathrm{die}^{(8)}$.

These parents also experience several regular changes due to the need for frequent hospital admissions, which lead to job loss, separation from other members of the family and their own homes, in order to fully assist their sick child; they can also have extra expenses resulting from this new situation and even fall ill $(3,9)$.

Given this scenario, it was observed that the treatment of childhood cancer, as well as its diagnosis, may cause a significant imbalance within the family, affecting the daily lives of not only the sick children and adolescents, but also of the whole family, especially the parents who are faced with unexpected situations and experience distress and uncertainty that involve this process.

Therefore, this study was aimed at understanding the experience of parents of children and adolescents with cancer undergoing treatment. It is believed that the results of this study may contribute to redirecting the actions of healthcare professionals, particularly those in the nursing area, and encourage them to seek to understand the needs of these parents. And, from this, in addition to the technical and scientific care, to be able to hear their concerns and fears, helping them with their sorrows and providing support aimed at these parents' integrality, in their condition of human beings, throughout the course of their children's treatment.

\section{Method}

This is a qualitative study, with phenomenological approach based on Heidegger's assumptions. In order to use this approach to seek to understand the event to be revealed, it is necessary to be involved in the daily lives of people and unveil their essence through the analysis of their languages and their experiences ${ }^{(10)}$.

From this perspective, the inquiry area or onticontological area was the situation in which the event took place, that is, the experience of parents who have childhood cancer present in the lives of their children. Thus, this study was carried out in a charity association located in a city in the Northwest of the state of Parana, which provides social and nursing care to poor people with cancer and their families.

In their records, eight families that had one member with childhood cancer, aged between zero and 19, were tracked down ${ }^{(1)}$. Therefore, it was decided to include as participants all parents, whether or not biological, who agreed to participate in the study and were able to clearly describe their experiences, and whose children were undergoing treatment or periodic monitoring after completion of the treatment.

The interviews were conducted in the period from December 2011 to March 2012. The initial contacts were made by phone or at the addresses provided, when the objectives of the study and the importance of their participation were explained to the participants, and their suitability to the inclusion criteria was evaluated.

Of the eight located families, five fathers and eight mothers of children or adolescents with cancer met the inclusion criteria, totaling 13 participants. They were asked the following guiding question: "How was/ has it been to experience the treatment of a child with cancer?" The interviews lasted in average 31 minutes and were held in the day, time and place of the parents' preference, with the use of a digital recorder to record their statements. 
To fully capture the expression of the subjects, careful reading of each statement was initially performed, and the parts or units of meaning that seemed to be essential structures of the existence were separated. They were later analyzed through the phenomenological selection of each subject's statement, since a unit of meaning is generally composed of feelings revealed by the deponents who contemplated our ontic-ontological questioning(11) and from which ontological topic emerged and were interpreted with bases on the ideas of Heidegger and authors who follow the philosopher, as well as researchers who discuss the issue of childhood cancer within the family.

In order to protect the identity of the participants, they were nicknamed after gemstones because, as these wear out and are cut in the process of polishing in order to become beautiful and shine ${ }^{(12)}$, these parents are seen as being polished as a consequence of their situation, and their statements show that somehow they are learning and/or maturing with the disease of their children.

Due to the fact that this research involves human beings, all ethical and legal rules regulated by Resolution number $466 / 12$ of the CNS-MS were complied with. The request for the participation in the study was accompanied by two copies of the Informed Consent Form, and the research was approved by the Research Ethic Committee of the Universidade Estadual de Maringá, under registration number 714/2011.

\section{Results and discussion}

Of the 13 participants in the research belonging to eight families, five were fathers and eight were mothers, aged between 21 and 74; most of them married/in a de facto relationship and Catholic, only 2 had completed Higher Education, and their occupation were: a packer, a driver, a jeweler, a retired farmer, an analyst, two craftswomen and a teacher, in addition to five self-called housewives. Of the eight children with cancer, four were children aged between ten months and 11 years: two had Wilms tumor, one had pelvic tumor and one, bone sarcoma; and four were teenagers aged between 12 and 18: one had testicle rhabdomyosarcoma, one had leukemia, one had brain tumor and one had lymphoma. All of them were undergoing and had already undergone some type of treatment (surgical, chemotherapy, radiation therapy and/or drug therapy).

Based on the analysis of the subjectivity expressed by the participants, three ontological topics emerged: "Experiencing the unpleasantness of the treatment";
"Fearing the possibility of a frightening situation"; "Experiencing the carelessness of another person", which will be presented below:

Concerning Experiencing the unpleasantness of the treatment, the Heidegger's existential analysis can be reported to, which is based in the situation of the Being while existing-in-the-world and proposes to describe the experience of human beings from the moment they become aware of their existence-in-the-world and understand their diversities. In this existential condition, human beings are in the world regardless of their will, and they are exposed to unplanned situations that were not envisaged by them and that leave them in the hands of the events ${ }^{(10)}$.

From this perspective, when cancer invades the life of their children, parents feel defeated by the impossibility of seeing the dreams they had for their children become reality and, at these times, they are involved by feelings of strong awkwardness and impotence, as per the following statement:

I imagined children with cancer only on TV, I could not see myself together with the bald child, with a sick child. Over time, they become weaker, sicker and that makes you feel small in relation to the child (Topaz).

The body is not only a physical organism, but a totality, a framework in relation to the things that are around it, that is, the sense is something that happens in the body itself: "It is a set of meanings experienced towards your balance: a new tie of meanings"(13). Based on this idea, it was denoted that Esmeralda was in shock when she found out that her son had bone cancer and had to be submitted to an amputation, which made her transcend the present, immerse herself in time and imagine how the life of her son without a foot would be, how he would walk around his world.

I did not believe I would have to go through this, it was very [...] [silence]. I thought I would not make it, a child without foot, how will it be? How will he stand up? How will he walk? And what about school? You know, these silly thoughts [...] (Emerald).

Listening to the mother's words, it was noted that the situation of her son was not something incorporated into her existence, since she expresses it with a lump in her throat, showing a silent agony. In relation to this issue, it was observed in the literature that when dealing with cancer, some parents, fearing something imprecise that is about to come, have the feeling of experiencing a battle, and ask themselves the reason why the disease invaded the lives of their children and their own lives ${ }^{(14)}$. 
Therefore, the anxiety structures the participants within their own temporality ${ }^{(10)}$, that is, experiencing this present moment that was not planned for their lives and, at the same time, remembering the past strength they used to have, being parents of healthy children who used to run and play around them.

[...] Because it is really not easy, it is very hard, very much so. And it is complicated, you see your child well, going to school, because he was a child who always ate well, ran, played, went to school, then everything suddenly stops, you see he spends more time in hospital (Ruby).

I do not like looking at photos of her on Orkut, in the computer, because she was such a pretty child, so perfect and, regardless of our wish, and it is even bad to say it, but she became an ugly child, she got very swollen (Topaz).

The conceptions of the parents encourage the thought that the children's illness made them to wake up from a good dream, full of satisfactions and pleasures, and started to envision a world of nightmares. /Among tears and sobs, they see their children being deprived of a life of playing and studying, unable to eat what they want, besides being physically deformed. And besides seeing the lives of their children being changed by the treatment, they realize that their own lives are taken by unfamiliar habits that need to be acquired and incorporated into their daily lives, so that they can overcome the obstacles resulting from this process, as it can be noted in the statement below:

The treatment itself is difficult, it requires our discipline, there are a lot of things that need to be changed. We have learned some habits that we normally do not have when the immunity is good, [...] it demands a little, but we have to do it (Pearl).

In Heidegger's s analytics, the Being, while a beingin-the-world always exists in relation to something or someone and, in this condition, understands their experiences and establishes own meaning to things and people in their world, and meaning to their existence. From this perspective, the tools or objects are not a purely subsistent reality, but is necessarily available for a specific use. The tool is basically something that human beings use to live in the world ${ }^{(10)}$.

Based on this, Amber's statement shows that, due to the strict treatment of her daughter, she is forced to get rid of objects she likes and that, to her, were important things that adorned her home.

I got rid of my little dogs, I had a hairy little dog, had to get rid of my little cat, there were plenty of cushions in my living room and I had to move them all away, remove the carpet, remove everything [...] because their immunity becomes very low. It is not easy, our day-to-day life is complicated, one has to give up a lot of things [...] (Amber).

The treatment of a child with cancer directly affects the parents, bringing significant changes to their daily lives, and even making them give up their personal belongings in order to protect their children from complications resulting from the therapeutic process. Thus, the various changes experienced since the detection of the disease until the beginning of the treatment become a striking and significant experience in their lives ${ }^{(15)}$

As for Fearing the possibility of a frightening situation, fear can be analyzed through the existential analytics under three perspectives and, among them, "what you fear" (Wovor), or the frightening, is studied. The human being is afraid of a being that comes towards them within the world, whether this is a simply given being or one represented by other beings(10). In this sense, it is believed that "being afraid for or being afraid of something always opens - whether privately or positively - in an equally originating way, the intramundane Being in their possibility to threat and the Being in relation to being threatened"(10).

Given this idea, it could be noted by the statements of the parents that the cancer, in the condition of a simply given being that came to their lives, brought with it not only distress and suffering caused by the treatment, but also the frightening threat of their loved child's death.

[...] she went through a very strong chemotherapy, everything was bleeding, the nose was bleeding, the mouth was bleeding, she was really unwell, and I used to say "Have mercy, my God", I was very distressed, very sad [...] the doctor told me that she was not going to survive past that week, that she was very unwell $[. .$.$] (Aquamarine).$

[...] I was desperate, he had to have surgery [...] we are talking about a disease that kills people, and really kills them, we are talking about cancer and in a bad place [...] (Diamond).

In relation to the issue, the literature mentions that both the adverse reactions resulting from the treatment and the worsening of the health condition, lead parents to feel anxious due to the pain and suffering which their child is in ${ }^{(8)}$.

It can also be highlighted that in this present moment experienced by the participants, to witness the death of other children makes this event to also become something that is possible to happen in their lives, because the frightening event is not yet in a manageable distance, but it is closer, and what was far away can become close or disappear, since "when it comes closer, the damaging event brings with it the unveiled possibility 
of leaving it and moving on, which does not reduce nor settles the fear, but, on the contrary, establishes it"(10).

And, in this establishment, the own Being releases to themselves the threat that they allow and are touched by. Concerning the issue, authors point out that the pain felt by parents who had their children killed by cancer becomes part of the thoughts of those who still have theirs under treatment ${ }^{(16-17)}$.

As soon as we arrived at the hospital, the apprehension increased even more because we had the chance to see, for example, children who had the same problem, who did not resist the surgery, did not survive, and this left us extremely stressed out [...] (Opal).

[...] I saw many children die there, and I had that in my mind; is my child also going to die, My God, is he also going to die? (Sapphire).

In Heidegger's analytics, the closeness to the frightening belongs to the structure of the meeting between the Being with the being that threatens it, even though this warning has not yet happened, it can happen at any time. And, this intimidation suddenly weakens the being-in-the-world and the fear becomes panic, a sudden distress that involves the human being in their existence in the world(10). There was distress in the expression of the parents when reporting their experiences on the face of the uncertainties about the future of their children, being always unsure as if the undesirable presence was going to knock at the door at any minute.

I was worried, only had bad thoughts; if three or four days passed without anyone coming over, I called the hospital. Sometimes I called but they did not give any information; I thought 'something happened'. [...] The dog barking, any little thing, someone clapping their hands, to me means already bad news (Alexandrite).

But from time to time, there is that fear, what about when the chemotherapy stops? Because it is when chemotherapy stops that the disease comes back, and I think I am not able to go through that again, I think that she would not handle it [...] (cry) (Turquoise).

The Being, while in the world, experiences the existential possibilities which are intrinsic to the own human condition. In this sense, the following statements show the distress of the parents when they find out that, after a relaxing period with the improvement of their children's health condition and, just when they believed that the cure was forthcoming, the cancer returns to be present in their lives.

[...] everything is starting over again; then there is a time when you say 'My God, will I lose my daughter?', because it is not easy to be hopeful and think that things are improving and suddenly you are hit with that, everything she has been doing in the past months has been in vain, there was no result $[\ldots]$ (Ruby).

We were very concerned with this second tumor $[\ldots]$ because I do not know where it comes from; there was nothing and you suddenly have an MRI and the thing is there. And then, he has no symptoms; maybe when he has a symptom, there won't be more time to save my son (cry) [...] (Pink Tourmaline).

About this issue, studies show that parents of children with cancer undergoing treatment are exposed to several insecurities related to the course of the disease and to the success of the treatment used ${ }^{(3,18)}$. Therefore, to recognize the insecurities and fears that surround the recurrence may help the nursing team to develop a better understanding of this event and its challenges, and to promote more open and honest communication during this critical period(19).

The ontological topic Experiencing the carelessness of another person refers to the Heidegger's idea that the being-in-the-world, due to their disposition, has a way of existing in which the presence opens to themselves and to others when thrown in the world. And, in this condition, being-in-the-world with other beings is an essential part of the human existence, is a being-with, characterized as care, that is, when being-in-the-worldwith-others, Dasein is always cared of ${ }^{(10)}$.

But existing-in-the-world, the human being may be uncovered in the deficient ways of care, characterized by a state of decline of the human being, that is, when the individual deviates from their essential project of being a care Being, and is absorbed by everyday futilities, revealing themselves in the occupation way of being, that is, the way of being that is driven by indifference(10), because the other is not part of their care, is not someone important. In the following statement, the participant expresses through his language all the sadness before the indifference showed by the other.

Sometimes you go to Santa Casa and you are neglected; you explain 'this needs to be done'. I think that it is a little negligence because I recently arrived there with her with a fever and the two more accidents were brought by the firemen 'ah, we have to prioritize the emergency', and I said 'but you did know my case is also an emergency, I was only not brought by the firemen, but I have two hours to medicate her' [...] (Turquoise).

Concerning Turquoise's statement, it was observed that he experiences distress while seeking his daughter's cure as he feels that the healthcare team does not care about the anxiety of a father and are not helpful with him. In relation to this, authors point out 
that, during this difficult journey, families interact with several professionals from various healthcare services and are faced with an evident lack of preparation on the part of these professionals to provide care to children with cancer $^{(15)}$.

However, the literature also reinforces that, in cases of life threatening diseases such as cancer, the nursing care provided to patients and families should be aimed at providing comfort, promoting the personal growth of everyone involved, recognizing tiredness and overcoming, among other care acts, and also bring to themselves and to others the meaning of these experiences $^{(20)}$.

Thus, the relationship with a helpful and committed team in the care for their children makes parents feel safe and protected, which positively influences all this process. Because when parents are going through difficulties and suffering, knowing that there are professionals who are willing to offer the support they need, makes them feel stronger to continue the battle(14,21).

In Heidegger's meditation, the language is part of the existential ontological of the being-in-the-world and represents a positive event, that is, the way the human being is and understands the world in their daily lives, reaching out others with words of comfort and joy. However, it can be noted by the language of the parents that the communication experienced by them does not carry in itself the ontological reference of what is spoken, that is, it never communicates through a genuine adaptation of the real fact and only repeats and passes through the statement of the world(10).

The following statements reaffirm the negative and persistent representation attributed to cancer and its therapeutic process, which are used by people to develop statements with no real knowledge, only repeating what they heard about unsuccessful cases.

And many people around us have supported us, but others used to say 'you have to be strong', 'you have to be prepared for whatever happens in the future'. And, honestly, we did not have any experience about it, and there was that great apprehension, that huge distress (Citrus).

[...] there are people who offer a friendly word, but there are people who come to your door only to tell you stupid things 'someone has also died from this', 'that person ate this and died', 'someone with this did not last one month', 'this disease is incurable', 'this disease really kills', only to tell you this (Amber).

In the study, it could be observed that, in these circumstances, people who share these experiences with the families can influence the way they cope with it, through their words, attitudes and actions throughout this process, and are able to provide them help or make things worse for them due to the efforts they make to incorporate the cancer event into their lives and into the lives of other family members ${ }^{(14)}$.

\section{Conclusion}

Through this study, it was possible to note aspects that are intrinsic to the experiences of fathers and mothers of children with cancer, who have undergone or are undergoing treatment, since they experience complications with their children and suffer by imagining how their future will be, which makes them wish for not only the control of the disease but, above all, the cure, to relieve their children's suffering.

In their existential circumstances, they have their lives suddenly invaded by the disease and start to experience the fear of the unknown, surrendering to the uncertainties and suffering when the fear of the death inevitably takes over their thoughts. This particularly occurs when they see the death of other children, leading them to feel distress by imagining the death of their own children. This feeling remains inside them, hidden from other people around them, particularly the professionals who have several times treated them with disregard and made them feel lost and insecure when in need of help.

Thus, when immersed into their mundaneness, it can be noted that this Care Being also needs to be taken care of. They are unique and composed of a disguised subjectivity, which is manifested through several ways and people, in their everyday lives, cannot even realize it, since they are busy with the futilities of the world. However, as the nurses put themselves in a position of co-responsible for providing care to these beings, they are capable of identifying their existential needs, either social, emotional or spiritual, and should conduct new care actions in all of their dimensions.

The present study shows the experience of parents who go through the treatment of childhood cancer in the lives of their children, who live in a medium-sized country town that does not have a specialized local service, and this can be considered a limiting factor of the research, since it does not allow generalization of the results. However, this has shown to be relevant in so far as it allows healthcare professionals, particularly those in the nursing area, to rethink their actions while with these beings since, when with others, it is possible to influence their situation and help or make it worse in relation to coping with the therapeutic process. 


\section{References}

1. Ministério da Saúde (BR). Instituto Nacional do Câncer. Coordenação de Prevenção e Vigilância do Câncer. Câncer da criança e do adolescente no Brasil: dados dos registros de base populacional e de mortalidade. Rio de Janeiro: INCA; 2008. 220 p.

2. Valle ERM, Ramalho MAN. O câncer na criança: a difícil trajetória. In: Carvalho VA, Franco MHP, Kovács MJ, Liberato RP, Macieira RC, Veit MT, et al, organizadores. Temas em psico-oncologia. São Paulo: Summus; 2008. p. $505-16$

3. Oliveira RR, Santos LF, Marinho KC, Cordeiro JABL, Salge AKM, Siqueira KM. Ser mãe de um filho em tratamento quimioterápico: uma análise fenomenológica. Ciênc Cuid Saúde. 2010;9(2):374-82.

4. Barreto TS, Amorim RC. A família frente ao adoecer e ao tratamento de um familiar com câncer. Rev Enferm UERJ. 2010;18(3):462-7.

5. Lombardo MS, Popim RC, Suman AL. From omnipotence to exhaustion: the perspectives of adolescents in drug therapy. Rev. Latino-Am. Enfermagem. 2011; 19(3):531-9.

6 Ferreira NML, Dupas G, Costa DB, Sanchez KOL. Câncer e família: compreendendo os significados simbólicos. Ciênc Cuid Saúde. 2010;9(2):269-77.

7. Jobe-Shields L, Aldefer MA, Barrera M, Vannatta K, Currier JM, Phipps S. Parental depression and family environment predict distress in children prior to stem-cell transplantation. J Dev Behav Pediatr. 2009; 30(2):140-6.

8. Nascimento CAD, Monteiro EMLM, Vinhais $A B$, Cavalcanti LL, Ramos MB. O câncer infantil (leucemia): significações de algumas vivencias maternas. Rev RENE. 2009;10(2):149-57.

9. Santo EARE, Gaíva MAM, Espinosa MM, Barbosa DA, Belasco AGS. Taking care of children with cancer: evaluation of the caregivers' burden and quality of life. Rev. Latino-Am. Enfermagem. 2011;19(3):515-22.

10. Heidegger M. Ser e tempo. 3a. ed. Petrópolis: Vozes; 2008. 598 p.

11. Josgrilberg RS. O método fenomenológico e as ciências humanas. In: Castro DSP, Ázar FP, Piccino JD, Josgrilberg RS, organizadores. Fenomenologia e análise do existir. São Paulo: Sobraphe; 2000. p. 75-93.

12. Franco RR, Campos JES. As pedras preciosas: noções fundamentais. São Paulo: Editora São Paulo; 1971. 155 p.

13. Merleau-Ponty M. Fenomenologia da percepção. $3^{a}$. ed. São Paulo: Martins Fontes; 2006. 662 p.
14. Angelo $M$, Moreira $P L$, Rodrigues LMA. Incertezas diante do câncer infantil: compreendendo as necessidades da mãe. Esc Anna Nery. 2010;14(2):301-8.

15. Silva TCO, Barros VF, Hora EC. Experiência de ser um cuidador familiar no câncer infantil. Rev RENE. 2011;12(3):526-31.

16. Castro EHB. A experiência do câncer infantil: repercussões familiares, pessoais e sociais. Rev Malestar Subj. 2010;10(3):971-94.

17. Menossi MJ, Zorzo JCC, Lima RAG. The dialogic lifedeath in care delivery to adolescents with cancer. Rev. Latino-Am. Enfermagem. 2012;20(1):126-34.

18. Santos LF, Marinho KC, Oliveira RR, Siqueira KM, Oliveira LMAC, Peixoto MKAV, et al. Ser mãe de criança com câncer: uma investigação Fenomenológica. Rev Enferm UERJ. 2011;19(4):626-31.

19. De Graves S, Aranda S. Living with hope and fear the uncertainty of childhood cancer after relapse. Cancer Nurs. 2008;31(4):292-301.

20. Pimenta CAM. Cuidados paliativos: uma nova especialidade do trabalho da enfermagem? Acta Paul Enferm. 2010;23(3):7-8.

21. Lima AS, Silva VKBA, Collet N, Reichert APS, Oliveira BRG. Relações estabelecidas pelas enfermeiras com a família durante a hospitalização infantil. Texto Contexto Enferm. 2010;19(4):700-8.
Received: Apr. $28^{\text {th }} 2013$ Accepted: Mar. $13^{\text {th }} 2014$ 